\title{
Chronic granulomatous disease presenting as an oculomucocutaneous syndrome mimicking Behçet's syndrome
}

\author{
D. Kelleher, F.J. Bloomfield, T. Lenehan, M. Griffin, C. Feighery and S.R. McCann
}

Departments of Clinical Medicine, Immunology and Haematology, St. James's Hospital and Trinity College, Dublin, Republic of Ireland

\begin{abstract}
Summary: A female patient who presented for the first time at the age of 19 with oculomucocutaneous syndrome was found to have an absolute deficiency of neutrophil peroxide production. Neutrophil peroxide production as measured by chemiluminescence was zero on stimulation with opsonized zymosan. Direct membrane stimulation with FMLP and calcium ionophore also failed to elicit peroxide production. The diagnosis of chronic granulomatous disease should be considered in young patients with oculomucocutaneous syndrome.
\end{abstract}

\section{Introduction}

Chronic granulomatous disease (CGD), an absolute defect in neutrophil peroxide production has been a recognized cause of recurrent infection in childhood since 1957 (Berendes et al., 1957). While the majority of patients with this condition inherit it as an X-linked recessive disorder, other patterns of inheritance include autosomal recessive and autosomal dominance with variable penetrance (Gallin et al., 1983). A quantitative defect in cytochrome-b-245 has been demonstrated in neutrophils from patients with the Xlinked form while the defect appears to be qualitative in the non-X-linked form (Segal et al., 1983). Females with the non-X-linked form may present late, in contrast to the X-linked form where the majority of cases present early in childhood.

\section{Case report}

A 19 year old woman presented in 1979 with a 3 month history of oral and vaginal ulceration. In addition she complained of headaches and blackouts over the previous two weeks. Her past history included hospital admission age 9 for antral washouts following sinusitis. At age 16 she developed otitis externa with abscess formation treated with antibiotics. There was no childhood history of skin abscesses, otitis media or chest infections. Family history was negative for

Correspondence: S.R. McCann, F.R.C.P.I., M.R.C.Path., Department of Haematology, St. James's Hospital, Dublin 8, Republic of Ireland

Accepted: 14 November 1985 infections, or auto-immune disease. Examination revealed multiple discrete punched out ulcers 1 to $1.5 \mathrm{~cm}$ in diameter at the vulvovaginal junction. In addition she had similar smaller ulcers on the tongue and hard palate. Ophthalmological examination revealed papilloedema. Skin examination revealed an acneiform rash on the face with, in addition, severe furunculosis over the face and upper trunk. Full blood count was normal. Computed tomographic (CT) scan showed no evidence of a space occupying lesion and the ocular findings were thus consistent with benign intracranial hypertension. Biopsies of the cervix, endometrium and vulva revealed severe inflammation with necrotizing vasculitis affecting veins and transmigration of acute inflammatory cells through the surface epithelium. Culture of a high vaginal swab grew Escherichia coli on one occasion. During this admission she developed a pyrexia of $38.5^{\circ} \mathrm{C}$ with arthralgia. Blood cultures were persistently negative. She was treated with broad spectrum antibiotics. While the pyrexia settled, her ulceration did not heal for a further 6 months. She re-presented in 1981 with oral and vaginal ulceration and was treated at this time with topical agents. Ulceration once again healed over a 3 month period.

In 1982 she presented with subaxillary abscesses and a large submandibular abscess which required surgical drainage. Cultures of both revealed infection with Staphylococcus aureus. Normal investigations included haemoglobin, white cell count and differential, platelet count, leucocyte alkaline phosphatase, immunoglobulins $\mathbf{G}, \mathbf{A}$ and $\mathbf{M}$, complement profile and anti-nuclear factor. IgE was elevated $282 \mathrm{U} / \mathrm{ml}$ (normal $<100$ ). Polymorph morphology was normal.

(C) The Fellowship of Postgraduate Medicine, 1986 


\section{Materials and methods}

Investigations of neutrophil function were performed. Neutrophil chemiluminescence (CL) was measured according to a modification of the technique of Easmon et al. (1980) using $5 \times 10^{5}$ neutrophils, $10^{-5} \mathrm{M}$ luminol and opsonized zymosan, calcium ionophore $10^{-7} \mathrm{M}$ and formyl methionyl leucyl phenylalanine (FMLP) $10^{-7} \mathrm{M}$ as stimulants. Quantitative iodination (Pincus \& Klebanoff, 1971), a reaction which requires the presence of peroxide was also performed. Neutrophil chemotaxis, measured using a modified Boyden chamber technique and casein $0.2 \%$ as the chemoattractant, was normal. Four patients with Behçet's disease were studied as controls.

\section{Results}

Results are illustrated in Table I. Briefly, CL was zero using all neutrophil stimulants, indicating an absolute defect of neutrophil peroxide production. This finding was confirmed by the marked reduction in quantitative iodination. Incubation of normal cells in the patient's serum failed to inhibit CL suggesting that a serum factor is not involved. Patients with Behçet's disease had normal CL. All family members had normal $\mathrm{CL}$, and none had a positive anti-nuclear factor.

\section{Discussion}

The finding of deficient chemiluminescence indicates an absolute defect in neutrophil peroxide production diagnostic of CGD. In the X-linked form of CGD this is secondary to a quantitative defect in cytochrome-b245 in the NADH oxidase system. Our patient had normal levels of cytochrome-b-245 (data not shown) but may however have had a qualitative defect as previously described. It has however been suggested that the cellular defect in some patients with CGD is at a pre-activation stage in membrane depolarization (Gallin et al., 1983) which precedes the NADH oxidase step. Patients with CGD characteristically present with recurrent infections in early childhood. Presentation with an oculomucocutaneous syndrome has not previously been described.

The diagnosis of Behçet's disease is syndromic. The cardinal features of Behçet's syndrome are oral ulceration, genital ulceration and ocular inflammation (Behçet, 1937). However, there is considerable controversy regarding the clinical criteria required to established a firm diagnosis of Behçet's disease (Haim \& Gilhar, 1980). This patient fulfils the criteria of Curth (1946) who specified that two of the three components were necessary. Furthermore, she fulfils three of four major criteria (namely oral ulceration, genital ulceration and skin lesions) of the Behçet's Disease Research Committee of Japan (Shimuzo et al., 1979). In addition she had benign intracranial hypertension, which is a recognized manifestation of Behçet's disease (O'Duffy et al., 1971; Kalbian \& Challis, 1970). Neutrophil peroxide production as measured by NBT reduction has been found to be normal (Sobel et al., 1977) or elevated (Okudo et al., 1974) in Behçet's? disease. However, neutrophil chemotaxis is found to be accelerated (Sobel et al., 1977). While immune complexes are found in high titre in Behcet's disease (Levinsky \& Lehner, 1978), the possibility that neutro-

Table I Studies of leucocyte function in the patient, normal controls and Behçet's syndrome

\begin{tabular}{|c|c|c|c|}
\hline & $\begin{array}{l}\text { Patient } \\
\text { cells }\end{array}$ & $\begin{array}{l}\text { Control } \\
\text { cells }\end{array}$ & $\begin{array}{l}\text { Behçet's } \\
\text { cells }\end{array}$ \\
\hline $\begin{array}{l}\text { CL with zymosan } \\
\left(\mathrm{mV} / 5 \times 10^{5} \text { cells }\right)\end{array}$ & 0 & $80^{+}-24(10)$ & $105^{+}-24$ \\
\hline $\begin{array}{l}\text { CL with FMLP } \\
\left(\mathrm{mV} / 5 \times 10^{5} \text { cells }\right)\end{array}$ & 0 & $8^{+}-4(10)$ & - \\
\hline $\begin{array}{l}\text { CL with Ionophore } \\
\left(\mathrm{mV} / 5 \times 10^{5} \text { cells }\right)\end{array}$ & 0 & $21^{+}-5$ (4) & - \\
\hline $\begin{array}{l}\text { CL preincubated with } \\
\text { patient serum }+ \text { zymosan } \\
\left(\mathrm{mV} / 5 \times 10^{5} \text { cells }\right)\end{array}$ & 0 & $85,91(2)$ & \\
\hline $\begin{array}{l}\text { Quantitative iodination } \\
\mathrm{nM} 1^{-} / 10^{7} \mathrm{PMN} / \mathrm{h}\end{array}$ & 0.7 & $5.6-20.4^{*}$ & \\
\hline
\end{tabular}

*Normal range for laboratory.

CL: chemiluminescence; FMLP: formyl methionyl leucyl phenylalanine. The values are mean \pm s.d. 
phil receptors might have been blocked by immune complexes in this patient is ruled out by the finding that (1) preincubation of normal cells with patient serum did not inhibit CL and (2) stimulation with Ionophore A23187, a non-receptor dependent stimulant, did not activate the cells.

Thus, while this patient may be classified syndromically as Behçet's disease, our investigations have demonstrated the diagnosis to be chronic gran-

\section{References}

BEHÇET, H. (1937). Uber rezidivierende Aphthose, durch ein Virus verursachte Beschwure am Mund, am Auge und an den Gennitalien. Dermatologische Wochenschrift, 105, 1152.

BERENDES, H., BRIDGES, R.A. \& GOOD, R.A. (1957). A fatal granulomatosis of childhood: the clinical study of a new syndrome. Minnesota Medicine, 40, 309.

CURTH, H.O. (1946). Behçet's syndrome, abortive form (recurrent aphthous oral lesions and recurrent genital ulcerations). Archives of Dermatology, 54, 481.

EASMON, C.S.F., COLE, P.J., WILLIAMS, A.J. \& HASTINGS, M. (1980). The measurement of opsonic and phagocytic function. Immunology, 41, 67.

GALLIN, J.I., BUESCHER, S.E., SELIGMANN, B.E., NATH, J., GAITHER, T. \& KATZ, P. (1983). Recent advances in chronic granulomatous disease. Annals of Internal Medicine, 99, 657.

HAIM. S. \& GILHAR, A. (1980). Clinical and laboratory criteria for the diagnosis of Behçet's disease. British Journal of Dermatology, 102, 361.

KALBIAN, V.V. \& CHALLIS, M.T. (1970). Behçet's disease; report of twelve cases with three manifesting as papilledema. American Journal of Medicine, 49, 823 .

LEVINSKY, R.J. \& LEHNER, T. (1978). Circulating soluble ulomatous disease. Patients presenting with oral and genital ulceration should have an assessment of neutrophil function performed.

\section{Acknowledgement}

The authors thank Professor John Bonnar for referring the patient. immune complexes in active Behçet's disease. Clinical Experimental Immunology, 34, 213.

O'DUFFY, J.D., CARNEY, J.A. \& DEODHAR, S. (1971). Behçet's disease: Report of 10 cases, 3 with new manifestations. Annals of Internal Medicine, 75, 561.

OKUDA, K., TANOKORO, I. \& SEKIDO, M. (1974). The NBT test in Behçet's syndrome. New England Journal of Medicine, 290, 915.

PINCUS, S.H. \& KLEBANOFF, S.J. (1971). Quantitative leucocyte iodination. New England Journal of Medicine, 284, 744.

SEGAL, A.W., CROSS, A.R., GARCIA, R.C., BORREGARD, N., VALERIUS, N.H., SOOTHILL, J.F. \& JONES, O.T.G. (1983). Absence of cytochrome b 245 in chronic granulomatous disease. A multi-centre European evaluation of its incidence and relevance. New England Journal of Medicine, 308, 245.

SHIMUZU, T., EHRLICH, G.E., INABA, G. \& HAYASHI, K. (1979). Behçet's disease (Behçet's syndrome). Seminar on Arthritis and Rheumatism, 8, 223.

SOBEL, J.D., HAIM, S., OBEDEANU, M., MESHULAM, T. \& MERZBACH, D. (1977). Polymorphonuclear leucocyte function in Behçet's disease. Journal of Clinical Pathology, 30, 250 . 